\title{
Emulsion for Suspension for Injection Dosage Form
}

National Cancer Institute

\section{Source}

National Cancer Institute. Emulsion for Suspension for Injection Dosage Form. NCI

Thesaurus. Code C149483.

Liquid sterile preparation consisting of an emulsion intended for use in the preparation of a suspension for injection. 